\title{
An artist's narrative self-construction: a conversation with Astrid Salles
}

Quote: SANTHIAGO, Ricardo; SALLES, Astrid. An artist's narrative selfconstruction: a conversation with Astrid Salles. Porto Arte: Revista de Artes Visuais. Porto Alegre: PPGAV-UFRGS, v. 23, n. 38, p.211-220, jan.jun. 2018. ISSN 01037269 | e-ISSN 2179-8001. DOI: http://dx.doi.org/10.22456/2179-8001.80806

Translated by Roberto Cataldo Costa

Abstract: In an interview with Ricardo Santhiago, visual artist Astrid Salles revisits aspects of her formation in the field of artistic creation since her youth in the late 1950s, in the state of São Paulo, in order to review important topics of her life history. She graduated in Music and is recognized as the first woman to play the French horn in Brazil. Astrid worked in illustration and landscape representation and now calls herself a painter. In the conversation, she recounts, among other points, her encounter with sertanist Orlando Villas-Bôas, which was crucial for her to dedicate her visual art production to reinterpreting indigenous graphic patterns.

Keywords: Interview. Astrid Salles. Education. Painting. Indigenous graphic patterns.

How is an artist constructed in terms of narrative? This is a promising question among many that can be asked about oral accounts provided by creators. In addition to serving as information sources that enhance readings of works of art in different languages, oral history interviews resulting from dialogues with scholars and researchers are a unique way to know artists' personal and professional histories as they perceive and articulate them.

The following interview is a shining example of narrative self-construction by a creator: it is a dialogue with Astrid Salles, a São Paulo-based artist with a curious history, which started in and is pervaded by music. Her skill to play the French horn, in which she graduated, gave way to ingenuity in the use of materials and supports - drawings, collages, paintings on canvas and wood, among others - and the deepening of a plastic language inspired by geometry of indigenous graphic patterns. In the interview, we can understand how Astrid Salles remembers, interprets and ascribes meaning to her artistic and professional development process, in a sensitive and gentle narration.

In a way, the descriptions she offers about some of her works - collages using mixed techniques - are good metaphors for her interview, which a kind of assemblage composed by remembrance of important episodes, a posteriori revisions and interpretations, deliciously concrete descriptions about her everyday life and work process, opinions and worldviews, indications of the conditions of production of the interview and the intersubjective relationship that originated it. Like the work of art itself which is only fully realized in the encounter with the viewer - the interview is also amplified in the light of the many inquiries and readings that it raises.

\section{RICARDO SANTHIAGO:}

Astrid, I'd like to go through your life history a bit. I'd like to begin by recovering your first memories, your first moments, thinking about your family origins.

\section{ASTRID SALLES:}

Music first came into my life because I liked it very much. Luckily, I was close to my uncle Pedro Pigatti, who was a big fan of classic music and had a wonderful collection! I was much loved - the only granddaughter, the only niece - so he pampered me and initiated me in music. That was in Piracicaba, when I was very young - five or six. He'd put music on the record player and ask: "Astrid, is this Mozart, Beethoven or Haydn?" [laughs]. At first I wouldn't remember and I got everything wrong; then I learned and I was able to distinguish the styles. He was the one who put me in touch with classic music - which was very good for me, because I started to like music a lot. At six and a half I started learning the piano. It was also Mom's preference. Mom played the mandolin, Dad played the guitar, and this uncle played the piano very well. Mom liked the piano but she never studied it, so her dream was to have a daughter who could play it. And I fulfilled that dream.

My parents were teachers, they worked in the country, each time choosing a slightly better subject to teach, but while they were living in very inhospitable towns, without any comfort, with nothing, l'd stay with Grandma and with that uncle in Piracicaba - they were my female and my male figures. My parents would come on vacation, but I was really influenced by my uncle and my grandmother. Later we moved to Santo André, where I lived my youth in the 1950s. After Santo André, my parents chose [to 
work in] Piracicaba - their dream was to return because everyone came from there.

I went back there in 1959 and enrolled in music school - it was not music school yet, it was called Pro Arte. I started studying piano and also art with painters who gave private lessons there. It was very nice, because we'd go out, a group of painters, to paint scenes of the Piracicaba River, those surroundings with hills and little houses, we went to Tietê... It was impressionism at that time. So I had this very good academic basis. And I recommend everyone to have it, even if it's outdated, because all the bases are there: shadow, volume, perspective, what is in the foreground and what is the background, a notion of space... Even if you become a very modern or abstract artist later, it's interesting to have that base. And I had it. At the same time I studied piano at music school.

\section{RS:}

And that uncle who introduced you to music was not a professional?

\section{AS:}

No. He loved music, he was a pianist. Then in 1959, when I went to this music school, which became an official music school, I used to play in the [Piracicaba] orchestra as well. I started playing the timpani. Then the conductor, who was a composer - Ernst Mahle - said: "Astrid, you have to choose a nobler instrument for yourself". I said: "I love the French horn". And I do love the French horn! The sound of it is something that gives a sensation in the stomach, like... I love it! Then he said: "Oh, let's start with the French horn, then". A horn player from the Public Force Band, Antônio Romeu, was going to Piracicaba. He went to teach there. I studied with him for three or four years and I was the first woman in Brazil to play the French horn. No woman had ever played it because it was very unusual. In a small town, in 1958, 1959, they'd even make fun of me: "Ah, that's a soldier's instrument!" [laughs]. But I was proud of my little horn for the rehearsals of the orchestra. That was very good, it was a highly productive period... Then I got into several courses: chamber music, choir, I played to accompany ballet classes, I played the piano to accompany musical initiation lessons... After graduating I taught piano lessons there too, and I took all the courses. I got all training I could. My class was the first at the school - The
Ernst Mahle School of Music. Ernst Mahle was one of the sons of the [owners of] Mahle [trumpet-maker], which is big - but he'd spent all his money on music, on instruments. So we had harpsichord, viol, harp, you name it. He even had all the French horns - I never bought a horn because he'd lend it to me and other players.

My Uncle Pedro started playing with us. My two sisters, my two cousins and I, plus my uncle - it was the Pigatti Sextet, because we took my uncle's name. He was very smart: he was a chemistry teacher, he graduated as an agronomist, he won the state chess championship... I think that when a person has sensitivity to like music, but at the same time a rational mind to be a scientist and he knows how to play chess, that makes the perfect, wonderful circle. Einstein was like that, right? All the great ones!

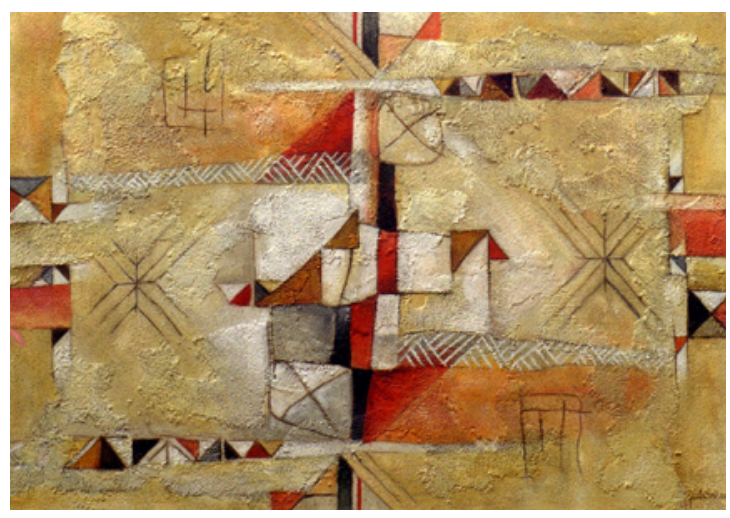

Figure 1. Astrid Salles. Graphic Patterns, 2002, mixed technique, 70 x $100 \mathrm{~cm}$. Photo: Astrid Salles.

RS:

Great thinkers, scientists, philosophers. It began to divide later.

\section{AS:}

Exactly! But those are people who can do everything, are interested in everything and are able to do everything... My uncle was wonderful! And I learned a lot, of course... He used to give me tips: "Do you know Carl Orff?" "No, I don't." “Ok, l'm going to record it for you." Well, I studied painting [with a] private [teacher], and in 1965 I had my first official participation in an art salon [in Piracicaba] - with a still life, of course. But it was very interesting! That part was very rich, even though it was academic, let's put it this way. After that I had other [teachers]. There was one who appeared in Piracicaba - Vladan Stiha - I don't know where he came from, but he was interesting because he taught details: 
how to draw noses, faces, hands... He addressed [it] piece [by piece]. It was very useful to me.

\section{RS:}

But, Astrid, what did you feel like doing at that time? What did you want to be when you grew up?

AS:

Well... I was going to be a pianist! I studied the piano much longer in my life than I studied arts. So I was going to be a pianist. I wanted it, I loved it; I dreamed, lived, drank and ate that art! I used to listen to that waltz from Khachaturian at lunchtime, the program "Music of the Masters" on Gazeta radio station... I listened to it because there was no television yet.

\section{RS:}

And how about being a teacher like your parents - did you think about it?

\section{AS:}

I was, actually. I graduated as a teacher. And I graduated as a teacher because what else could I do in Piracicaba? Normal [School], right? Or Agronomy - but I didn't want to study Agronomy at all [laughs]. In the first [year of] Normal School I still studied in Santo André in 1959, then I continued it in Piracicaba and I graduated there. Then I started to date a boy from São Paulo, we had an aunt in common. He played the bassoon and I played the French horn - music brought us together. We met at a party, started dating, and he fell for me. Then he proposed... that it-has-to-be-taken-seriously sort of thing. Well... I got married and lived with him for sixteen years. My two sons are from that first marriage. Dating was very good, because we often played together, we did chamber music, I accompanied him in a Mozart sonata for bassoon and piano...

Then I got married and came to São Paulo. I got married when my fiancé was still at the end of the [Largo de] San Francisco Law School. When he finished it, he worked for some time as a lawyer, but he decided to try a prosecutor's selection. While he was engaged in studying fro that, I stayed in Piracicaba studying painting with Álvaro Sega. It was good because [my husband] dedicated himself and was approved.
Then our life in small towns began, first in very simple ones. The first one he chose was Cafelândia, where we stayed at his grandparents' farm. He'd go to work in a buggy and I stayed at the easel, painting, it was like a $19^{\text {th }}$ century thing! [laughs] Then we went to Barra Bonita and after that to Conchas, when I started to attend Art College in Tatuí. I took an entrance examimation, I passed, and then I transferred it to FAAP in the second year.

\section{RS:}

Tatuí is also a very musical town, isn't it?

\section{AS:}

It is! I gave private piano lessons to a lot of students; I prepared them to take the exams for the Tatuí conservatory. I would take the program, they studied it with me and prepare for the audition! I didn't want to be in the prosecutor's shadow, to be the "prosecutor's wife"... I wanted to do something for myself. Teaching piano was at hand. I continued studying the piano later when I came to São Paulo, with Fritz Yank, and Arts at FAAP. I graduated in 1975 and in 1978 I collaborated in the establishment of the Museum of Contemporary Art of [the town of] Americana, where I taught painting and drawing, at the invitation of the city, to open people's minds so they could understand contemporary art and the museum. Then I ended up taking an examination to work at the Institute of Fisheries and the Institute of Botany and I worked as a scientific illustrator: I had to draw fish, animals, that sort of thing...

\section{RS:}

And how was that work? Did you watch and copy?

\section{AS:}

Mainly from other photos - not from nature. They were for books, for scientific publications... I illustrated fourteen books written by Dr. Marcio Infante Vieira - an agronomist from São Paulo. It was interesting, it was something I had to do, but it was not really my work.

RS:

It was not artistic, but you kept on doing it anyway. 


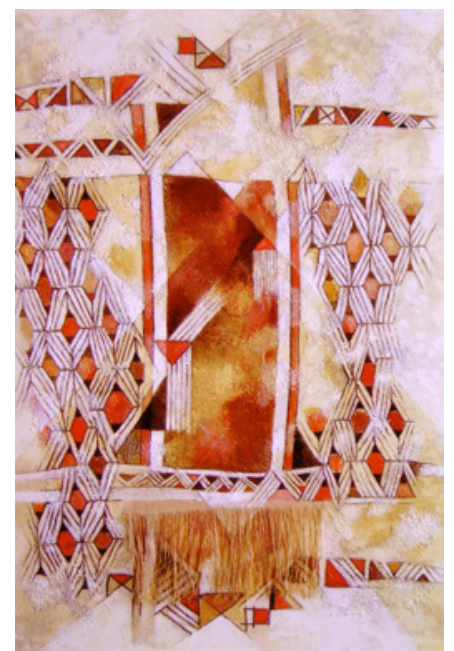

Figure 2. Astrid Salles. Mask, 2003, mixed technique, 100 x $70 \mathrm{~cm}$. Photo: Astrid Salles.

\section{AS:}

I did. I also set up a studio near Conselheiro Brotero Street - I used to live in Higienópolis. I rented a small room, set up my first studio and started working there. Then I met another guy who was an artist and we fell in love. I divorced my first husband and I dated this other guy until my divorce was done, and then I lived with him for a few years. It was different.

\section{RS:}

And during your FAAP period, what did you learn that was different? What did the School of Arts gave you?

\section{AS:}

It was incredibly mind-opening! Then that "academic" thing I knew, which I used to paint, from nature, it helped because you have nature copy classes there. I was a student of Tomoshige's [Kusuno] - he'd pose himself. José de Moraes taught printmaking, [Nicolas] Vlavianos taught sculpture... It was very good. We had to read a lot. Ivo Zanini used tom give us lots of things to read. And I was a teaching assistant for Professor Tereza Nazar, who was Vlavianos's wife. She chose me to be [an assistant] at her classes. I'd go to school in the morning, afternoon, and evening. Luckily I used to live close by, but it was pretty intense. FAAP was excellent at the time; it was different from other schools because - just look at all the artists who taught there... it was different from a Fine Arts school. It was not academic; it was really modern. So you had to relax, you had to choose your own style, right? So we struggle and struggle [until we find it]. In the 1980s, I already knew Orlando Villas-Bôas, but then my contact with him intensified. I wanted a Brazilian thing for my work; I was looking for something very Brazilian. I didn't want anything naïve; I wanted to go to the origins of Brazil. Then Orlando said: "Do you know anything more Brazilian than the Indians, our Indians?" Another sertanist [an expert in Brazilian sertão - or hinterland - culture who often lives among its people] I knew, who was also Orlando's friend, told me the same thing. Then I began to look into Indian drawings, their graphic patterns, and I was dazzled, fascinated! We always know a few things, but there I did a real research job, to see what they represented, how the geometry of the tortoise shell was, the jaguar skin, mosquito bites, snake bites... Only those who know it will understand it; it's totally geometric. So in the 1980 s I started working on that topic.

\section{RS:}

Within these indigenous themes, some people see "Indians" in a monolithic way, but there are different tribes, cultural differences... Did you study all this?

\section{AS:}

I did. There are over six hundred tribes, many languages, many things. Many were wiped out at that first encounter, but there are many others. Today Indians are recovering: they are having children, groups are getting stronger... But they are surrounded. The last time that friend of mine - he is deceased now - went to Xingu he said that the park was surrounded by soybean plantations. Poison spray was falling in the park, the garbage was accumulating and coming in, springs were polluted... It's difficult, it's brutal.

I had other phases before the Indian one. When I started [my development in art, after arts school], I had divorced my first husband. It was a very difficult relationship and a very difficult divorce because nobody accepted that I divorced a public prosecutor from a noble family of landowners. I started with [a series called] Ruínas [Ruins, around 1976]. 
RS:

Are they paintings of buildings in ruins?

\section{AS:}

Yes, they were ruins. They were pieces of walls. After a long time I began to include women's figures among those ruins. I think I had to elaborate that ruin within myself, the ruin of my marriage, which had taken a lot of effort to break up. It was very difficult, very complicated. But I was including [it on the paintings]: all the walls I had to bring down. Then I gradually included live figures - later.

RS:

But for you art is a way of...

\section{AS:}

I interpreted it that way. When my son Paulinho died, I also changed my style completely [around 1983]. I started with some desolate, dead landscapes, dried trees; it was an empty, very arid thing. I lived my mourning. When an artist sets out to do a work, he is there, exposed.

\section{RS:}

From what you told me, FAAP instigated you to seek your own language - but until you found it there was still some time for maturing.

\section{AS:}

There had to be! The first exhibition I got to do with the indigenous theme was in 1987 at Piracicaba's SESC and at Santos's Cades gallery. Those two exhibitions were the first ones [after] I found a way for myself. It was very good, with a lot of reviews and articles in the newspapers - even because if you leave São Paulo you get space. [At that time], I was no longer with my second husband; I was with Braz [Dias], who was an artist. In 1983 he had opened the gallery of Friederich Könning, a German man who lived in Brazil. He liked Braz's work and invited him to do this opening of his gallery in Schleswig. By 1987 we were already together and Friederich came to visit us. He knew my work and liked it very much; he bought everything I had and ordered 120 paintings. Then I did the exhibition there and sold very well. Over seventy percent of the exhibition was sold. It was a small town, but with highly educated people. Besides, we traveled a lot. I didn't know Europe and we traveled to The Netherlands, Germany, Italy, France, Belgium, and Denmark.

\section{RS:}

I wanted you to tell me about your relationship with Braz Dias, who accompanied you throughout your professional and personal life.

\section{AS:}

He was my longest relationship. I stayed with my first husband for fourteen years and I stayed with Braz for twenty-nine. We were close to our $30^{\text {th }}$ anniversary. He was a great companion. We loved each other so much, but we were close friends more than anything. And I admired him a lot as a person and as an artist. It was not just me - he was admired by all the artists. When we went to visit friends there were always lots of people around him, listening to what he was saying, because he had wonderful knowledge. In 1960, 1961, he'd been to Italy with a grant and everything, so he already had some experience, besides everything he read, the music he listened to, what he watched. He was more focused on culture than fun. He was an introspective guy with a very rich inner life. And it was very good - our encounter was great. At that time l'd lost my youngest son Paulinho and Braz's marriage was ending. So we met and it seems that our encounter was set in the stars, because the two of us suddenly discovered the world, you know? I was very sad after my son's death, which brought me down. He died in July and in October I started looking at Braz in a different way, and Braz to me. After we agreed that we were in love, he said: "Wow, for the first time I look at the end of a tunnel and I don't see a train. It's a light, it's not a train". And I said: "And to me it seems that there was a curtain that was gray, that would not let me see the light... Now the curtains have been opened..." What a beautiful thing this mature love was! It was mature love but my heart used to beat like a teenager's. It was like that. So it was very rich, very rich.

\section{RS:}

And the description itself is graphic, it's imagery, isn't it? To 
him, it was the end of the tunnel; for you, the curtain was opening.

\section{AS:}

It's true. There is always an interpretation as an image. But it was really like that; that's exactly what I felt. Wow! He made me feel very well! And I think I did that to him too, because we needed each other. We discovered love again.

\section{RS:}

I have some of his works and one of your works in front of me... The colors are already completely different; your work is completely different.

\section{AS:}

Because I was already an artist before that. Not that I had started painting because I was with Braz. So there was no influence from him. I already had my style and he had his. But we gave each other opinions, because we always worked together. When I did a work that I thought was almost ready, but I didn't know what I was missing, [l'd say]: "Braz, take a look and see what's missing". Then he would answer: "It lacks finishing! You have to do a lot more, work a lot more for that painting to be ready". He also asked me for opinions. Some of my opinions were good. Once he made holes in the ceiling and holes in the bottom that opened to another horizon - and he also made some holes in the floor. These holes in the floor gave an unpleasant impression. Some people told me, unintentionally: "Wow, it distresses me! It looks like I'm going to fall!" There should be some psychological reason for him to do this, but the he stopped and it was better that way. It was depressing.

\section{RS:}

They were holes that suggested a fall.

\section{AS:}

Yeah, I think it was very depressing. [changes subject] Together we did an exhibition in Penápolis, at the Museum of the Sun, which was very good. In 1987, when we went to Europe, they ordered 120 paintings from me and 264 prints from him. We had to hire a printer to help, because [without that]. We used a spoon - those very delicate xylographs! I put a clothesline in the studio to let it dry. It took a lot of work to meet that order. It was very good!

RS:

Did you make engravings, Astrid? I know you did serigraphs, prints ...

\section{AS:}

Yes, I did, but I didn't really develop it. I even thought that my indigenous work would go well with xylographs because they can have smooth cuts and rougher cuts. So I think I could work with African, Indian painting, something like that, but it was not my [choice].

RS:

Have you practiced it at some point in your training?

\section{AS:}

I did, because I had xylograph class, metal class, lithograph class, all that. [Evandro Carlos] Jardim was my printmaking teacher, a great artist, very good. But I think Braz was so splendid on it that we didn't need another... No. besides, if I had to do it, l'd do something different, but it didn't feel like it. I did drawing and painting, that's all.

RS:

And in painting did you start with oil?

\section{AS:}

Oil, yes. At that first moment in Piracicaba, when we were impressionist painters, let's say, we did everything in oil - still life and landscape, things like that. Then at FAAP I discovered acrylic. I already knew watercolor and gouache. Printmaking - it depends, if it's on metal, it's on the metal surface itself, there's also corrosion, pitch, that you can put in the pitch box to stick, make those several layers... And lithograph is done on stone, you have to apply wax around it so it will not cross, then you draw and separate the colors, drawing one part you want and the other you don't... That was my engraving of metal, xylograph and stone. Now 
there's digital prints and everything. But I preferred canvas and drawing. Another thing I've always liked was collage. I was part of the first collage group formed by Robert Richard, who was the mentor of all that.

\section{RS:}

These are collages with materials that you...

AS:

I would do it with everything: with hards, gauze, sand - it was a texture, let's say - with cotton strings... Especially rustic materials, because it referred to indigenous work. Indians never paint on flat, smooth surfaces; they paint on their bodies. The rest is pottery, wood, a stick, a weapon. But I'm more rustic than smooth - Braz is the opposite, you see? Braz is smooth, his surfaces are completely different from mine. Look, it's well contrasted. [The interviewee points to two works: Braz's has a large blue surface, with a very thin layer on the canvas; Astrid's is entirely filled with collages of rustic materials.].

RS:

What do you have on that screen?

AS:

Small tiles, sand, drawings, acrylic, modeling paste... There are several textures. There is sand and a preparation with sand, a thicker one; there are layers of sand and common sand. And there are the collages with graphic patterns. In order to make a painting, I need to draw. If I'm going to use texture, I need to draw it up to know more or less where I'm going to put it, because if I put texture in the whole picture, then the drawing will not pick up. So I start drawing the basics, let's say. Then I decide where to put the textures. If you have something - fabric, hemp, linen, interlining, bandage, gauze or something like that - I'll glue it on first. I use a lot of corrugated cardboard too. But I put it all before applying sand; this detail is already there, it can't [change it] anymore, what I am going to do is already decided. I also always balance it diagonally. It always gets very balanced.

RS:

Not symmetrical, but balanced.

\section{AS:}

Exactly. It's not symmetrical. Braz is more symmetrical; he used to do many things right at the center; his prints were right at the center. So fortunately we have very different styles.

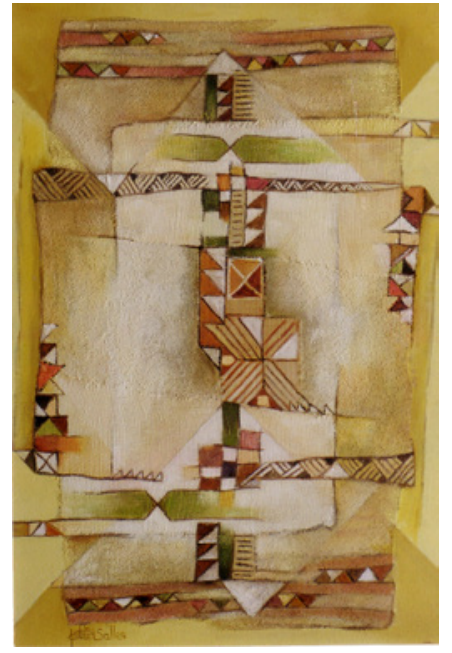

Figure 5. Astrid Salles. Sounds of the Jungle, 1998, mixed technique, $60 \times 40 \mathrm{~cm}$. Photo: Astrid Salles.

\section{RS:}

I imagine it takes a lot of work to make collages out of those materials.

\section{AS:}

Yes, it does!

\section{RS:}

It seems like cooking: there are several small things that need to be prepared before doing the work itself, right?

\section{AS:}

Yes. If I put pure sand, for example, I'll have to let it dry and then apply a protector, a fixative - I've used several things, now I use water-diluted PVA glue, which works the same way and protects it. I do the collage. I apply the sand. I fix it. Then it's when l'm going to paint. So yes, it's does take a lot of work.

\section{RS:}

How is your work pace? 
AS:

I'm faster. Braz was slower than me. I always do small sketches - smaller [than a canvas], but proportional. Then I move on to the painting and I do it. It gets a bit different from the sketch, because I improve it gradually. Sometimes I make a sample of colors, sometimes I leave the sketch in black and white and the color resolves itself with time. Braz was not much of a sketch maker either. He'd do one thing or another, but he already knew what he wanted. He was slower to finish a painting. I was fast. I'd say: "Braz, we have a show! Aren't you going to start your painting?" In the end he was ready on time: he thought a lot and worked fast.

\section{RS:}

How long does it take for you to do a job like this [about 80 $x 80 \mathrm{~cm}]$ ?

\section{AS:}

I can't tell you. If I work hard, I guess a week or two. Sometimes you start a work and get stuck, and you don't know how to end it. You need to give the canvas a rest. Then you call it again, you see other things that were missing, you know? It's a second look.

\section{RS:}

It's like writing: you let a text rest and then revise it.

\section{AS:}

Exactly! Then you go: "Gee, how didn't I think of that before?" That's how it is. This one [points to another painting] had a lot of texture and cardboard. It has gauze and some hards, too. Here [points to a third work] was modeling paste. I also use a lot of marble powder, which Antoni Tàpies used. He made art brüt with themes based on the problems of Spain. But if you abuse it the painting gets very heavy - heavy with weight, not in appearance. So we have to be careful.

\section{RS:}

How does a work begin, Astrid? Is it a shape, a support, some material you want to work with, an inspiration?
AS:

It's inspiration. For example, I did a series of things with stars, because of my name; a very irregular series, with indigenous patterns on the sides and creating another surface on top. Another series is much more indigenous [as she speaks, she points to examples of the works present in her studio].

\section{RS:}

You also like these circles very much - works done on wood pieces.

\section{AS:}

Circles, it's true. But I started painting half circles, which refer to beiju scoops. The Indians have these beiju scoops, which are semicircle-like tools on which they work, drawing on top, to distinguish them from any common wood. Just like the weapon, which is not a stick - it's a weapon with lots of drawings on it. It's art. If the Indians don't paint, they look like animals; they paint themselves to show that they are men. Art is intrinsic to Indians.

\section{RS:}

I asked you that question because l'd like you to talk a little about the banners - you've done a whole exhibition with banners.

\section{AS:}

It was the only thing I could do after Braz's death. I don't know why... Maybe because it's something more material, more like craftwork, so I got involved with it. I don't know how to explain it. But why the banners, eh? All these things l've been doing on MDF boards are actually attempts to get off the canvas. Moreover, the banner is something used in festivities, to be seen in motion; it's not a static thing. It's joy, it's celebration - at Carnival, for example. In processions, in turn, the banner bears images of saints. For me, they are mostly indigenous things. Another work that I did with wood pieces was the result of a course in Phenomenology of Art I took at USP in 2003. I chose Paulinho Nogueira's songs for my final work. I decided to work with music graphic patterns based on sheet music - I know sheet music, I wanted to do it in drawing. These are things that have to do with painting and with craftwork. I made two Kadiwéus on rectangular pieces, one in warm colors and 
one in cool colors, tracing the delicate graphic patterns of that tribe - the Kadiwéus have wonderful patterns, they are an atypical Brazilian tribe. They do round things; the painting on their faces, for example, is wonderful, very graphic. I developed many things based on them. Jacob Klintowitz [curator of the exhibition that showed the banners] was very fond of the snakes I did [with paintings on wood pieces]; he said that it was the strong part of my work. They are attempts to escape [the conventional] that don't always work - when you change a little, you have to struggle, to do a lot of it, to mature. Nothing is so fast.

\section{RS:}

You were talking about the music sheets - could you tell me a little bit about the work you did with Paulinho Nogueira, about his music sheets, and the exhibition you did with several songs about the city of São Paulo? Those were two moments when you brought your two artistic passions together.

\section{AS:}

Exactly! In this course of Phenomenology of Art, we studied lots of Duchamp, Klee, and especially Merleau-Ponty's philosophy. That's when I began to think; l'd see music sheets and think: "Wow, this is an indigenous graphic pattern!" [laughs]. Then I had the idea of bringing music sheets and visual arts together: I transferred their patterns to visual arts. Then I invited Paulinho to participate in the presentation. First I explained what it was: "Look, the music sheet will represent several things - technique, music, with the notes on top of it". He asked: "But who understands that?" And I said: "If you play it, they'll understand!" [laughs] And it was a success. Then it was São Paulo's anniversary. Valkiria lacocca, who was the curator of the [celebrations], invited me. I accepted the challenge and it was really hard work. I chose all the composers who had made music for São Paulo: Vanzolini, Mário Zan, all of them, from the oldest to the most modern ones. It was an immense exhibition, it opened at [commercial building] Conjunto Nacional. With that exhibition I actually won the Clio Award from the São Paulo History Academy. Soon after that, I participated in another celebration of São Paulo's anniversary, the exhibition A trip of 450 years, with Radha Abramo as curator.
RS:

You talked about Klee - do you recognize other influences in your work? I know you like Klee a lot.

\section{AS:}

And I let myself be influenced. I like his work very much. It was a great honor to see a live Klee exhibition in Europe, with those paintings I had seen only in books. Also I really like... what's his name again, a Spaniard linked to art povera, very rustic. I love his work. I like everything that is ethnic and searches for roots, as you can see from those little paintings that came back from Switzerland now. [points to three small works] Unfortunately, I sold very little. Many galleries have closed. The whole world has changed... The system has changed, the purpose has changed. People prefer to buy a new mobile phone or a new car than buying a painting. And the system in Brazilian galleries has also changed a lot. They have niches of interest: one gallery specializes in concrete art; the other is bringing in graffiti... My art is not highly contemporary; it's not an installation, so it doesn't interest much to anyone anymore. It's in the middle of the road it's not contemporary and it's not backwards, as they say.

RS:

So how does an independent artist survive?

\section{AS:}

Usually doing other activities. They give lessons, they sing, they write books, they make money as curators... Others have galleries and in the end they make money out of other artists, because today the galleries get very large percentages - which is justifiable in a way, because rent, taxes, expenses are very high. I have lots of friends who give lessons and they say that the number of students is also decreasing. I'm experimenting with artisan work, with other things for a varied public. But everything seems to be difficult.

\section{RS:}

Many artists end up negotiating with the market in one way or another. How do public tendencies or desires influence your work? Do you consider taking a certain direction because you think people will like it more? 
AS:

No, I don't. I've never considered it, except in these craft pieces. But my painting remains the same. It took me a lifetime to get to this style. I might change it: get more into the abstract, take on a different characteristic... I started with Indians: Indians' heads, headdresses, Indian women handling pottery... It was figurative work. Then I got more abstract and I was left only with the graphic patterns - only they are in my paintings. And I can't give that up.

\section{RS:}

Please tell me a little bit about your performance at São Paulo Artists' Association, APAP, in which you are involved, and where there seems to be a movement to deal with the realities of artists today - such as collective exhibitions promoted by the association.

\section{AS:}

We have completed 35 years of existence. That is why there have been so many celebrations: at Santos's Pinacoteca, at Marta Traba Gallery in the Latin American Memorial, at the Campinas Museum of Contemporary Art, at Mackenzie... I serve as APAP's first secretary, I go to meetings, every two months... I like that group, but I don't know how long I'll continue to participate. I'm slowing down every way. Recently, I even considered playing music again. I hired a French horn player to give me lessons, but then I thought I couldn't. I can't get into a hobby that is going to take up my time, which needs total dedication until the end of my days. I'm not a horn player anymore. It would be a nostalgic thing, a desire to stop time. So l've been more restricted to painting.

Astrid Salles: was born in Piracicaba, state of São Paulo. She graduated in Music and was the first Brazilian woman to play the French horn. She was honored by German composer Ernest Mahle in $O$ Concertino. After becoming an artist, she graduated in 1975 from FAAP. Encouraged by Orlando Villas-Bôas, she began an approximation with indigenous geometric and graphic patterns in the 1980s, which have marked her work ever since. She is the widow of painter and printmaker Braz Dias, with whom she shared the exhibition Braz Dias e Astrid Salles: o flautista azul e os estandartes (Braz Dias and Astrid Salles: the blue flutist and the banners), whose curator was Jacob Klintowitz in 2013. She lives and works in the city of São Paulo, where she also serves as secretary of the São Paulo Artists' Association (APAP).

Ricardo Santhiago: is a historian and communicologist. He holds a PhD in Social History from the University of São Paulo (2009), a PhD from the Fluminense Federal University (2015), and is currently a professor at the State University of Campinas, where he teaches courses related to Research Methodology and History of Science. Within his areas of expertise - Oral History and Public History - he studies artistic and narrative subjectivity. The books he authored and organized include Dissonant Soloists: Oral History of Black Singers (2009), Oral History in the Classroom (2015) and Oral History and the Arts: Narration and Creativity (2016).

$\left.{ }^{*}\right)$ This text was submitted in October 2017. 